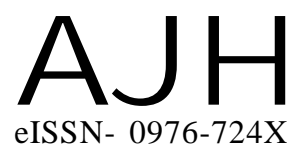

Article history :

Received : 06.09.2014

Accepted : 28.11.2014
Author for correspondence :

\section{KRISHNAMOORTHY}

Krishi Vigyan Kendra, Tamil Nadu

Agricultural University, Vamban Colony (PO), PUDUKKOTTAI (T.N.) INDIA

Email : krishorttnau@gmail.com
THE ASIAN JOURNAL OF HORTICULTURE

Volume 9 | Issue 2 | Dec., 2014 | 515-517

Visit us -www.researchjournal.co.in

\title{
Assessment of tuberose (Polianthes tuberosa) varieties for growth and yield characters
}

\section{KRISHNAMOORTHY}

ABSTRACT : The study was conducted by Krishi Vigyan Kendra, Tamil Nadu Agricultural University during 2013-2014 to assess the performance of high yielding tuberose varieties for Pudukkottai district of Tamil Nadu. The four varieties viz., Local cultivar, Phule Rajini, Arka Niranthara and Prajwal were planted in half acre each in the fields of five farmers at Arasaradipatti and Chettiyapatti villages during June 2013. The varieties were studied for various parameters viz., number of bulblets per clump, bulblets weight per clump, number of leaves per clump, leaf length, leaf width, leaf area index, days to first flowering, number of spikes per square meter area, number of spikes per clump, flowering duration of spike, spike length, number of flowers per spike, flower weight per spike, flower length, flower yield per clump, 100 flower weight and flower yield per hectare. The results revealed that among the four varieties, the Prajwal recorded significantly early flowering (153 days), no. of spike per clump (3.5nos/ clump), number of flowers/spike (44Nos/spike), flower per clump (144g), 100 flower weight (96g), flower yield per hectare (15.4t/ha) and benefit cost ratio (3.21) followed by Arka Niranthara recorded days to first flowering (175 days), no. of spike per clump (3 nos/ clump), number of flowers/spike (42Nos/spike), flowers per clump (122g), 100 flower weight (90g), flower yield per hectare (12.2t/ha) and benefit cost ratio (3.00). The Prajwal variety was found suitable for Pudukkottai district of Tamil Nadu.

KEY WORDS : Tuberose, Varieties, Spikes, Clump

HOW TO CITE THIS ARTICLE : Krishnamoorthy, V. (2014). Assessment of tuberose (Polianthes tuberosa) varieties for growth and yield characters. Asian J. Hort., 9(2): 515-517. 